\title{
Security, Local Community, and the Democratic Political Culture in Africa
}

Krzysztof Trzcinski

In this study, the idea of the local African community as a social structure ensuring the security of its members is presented. An understanding of the concept of security is first briefly discussed, followed by the meaning of the concept of the local African community. The chapter also makes an a priori distinction between what one can call "moderate" and "radical" types of communal life and two case studies exemplifying them are presented. The chapter aims to analyze the trade off, in terms of provision of security, including economic security, by local communities, for the shaping of a democratic political culture in Sub-Saharan Africa. Most importantly, however, this chapter also highlights the rationality that underpins the seemingly low-quality democratic political activities of members of local African communities.

The term "security" may be understood differently. It may refer to various entities, such as individuals, a nation (or other social groups), or a

K. Trzcinski $(\bowtie)$

Jagiellonian University, Krakow, Poland

(C) The Author(s), under exclusive license to Springer Nature

Switzerland AG 2021

A. Afolayan et al. (eds.), Pathways to Alternative Epistemologies in

Africa, https://doi.org/10.1007/978-3-030-60652-7_7 